\title{
Complete Non-Radioactive Operability Tests for Cladding Hull Chlorination
}

\section{Fuel Cycle Research \& Development}

\author{
Prepared for \\ U.S. Department of Energy \\ Fuel Cycle Research and Development \\ E. D. Collins, J. A. Johnson, T. D. Hylton, \\ R. R. Brunson, R. D. Hunt, G. D. DelCul, \\ E.. C. Bradley, B. B. Spencer,
}

Oak Ridge National Laboratory

Day-Month-2016

FCRD-MRWFD-

ORNL/LTR-2016/172

Approved for public release.

Distribution is unlimited. 
DISCLAIMER

This information was prepared as an account of work sponsored by an agency of the U.S. Government. Neither the U.S. Government nor any agency thereof, nor any of their employees, makes any warranty, expressed or implied, or assumes any legal liability or responsibility for the accuracy, completeness, or usefulness, of any information, apparatus, product, or process disclosed, or represents that its use would not infringe privately owned rights. References herein to any specific commercial product, process, or service by trade name, trade mark, manufacturer, or otherwise, does not necessarily constitute or imply its endorsement, recommendation, or favoring by the U.S. Government or any agency thereof. The views and opinions of authors expressed herein do not necessarily state or reflect those of the U.S. Government or any agency thereof. 


\section{CONTENTS}

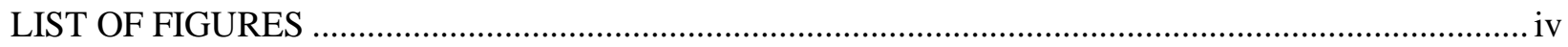

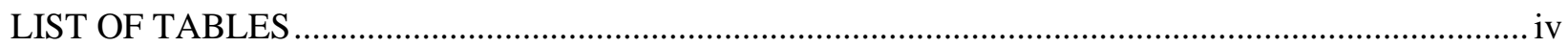

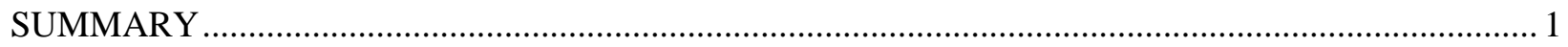

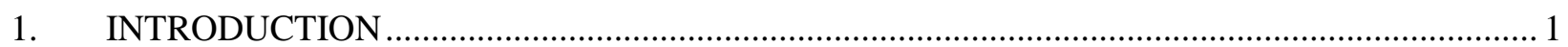

2. HEATING TO REACTION TEMPERATURE ........................................................................... 2

3. CHLORINATION TEST RESULTS AND OBSERVATIONS ….................................................. 2

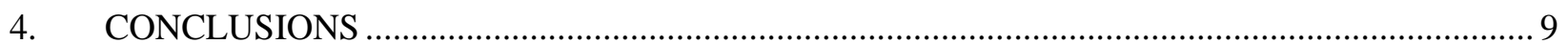




\section{LIST OF FIGURES}

Fig. 1. New metal test equipment for hot cell tests with 100-500g UNF cladding per test. ...................... 2

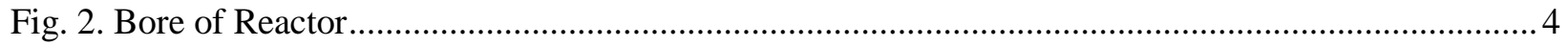

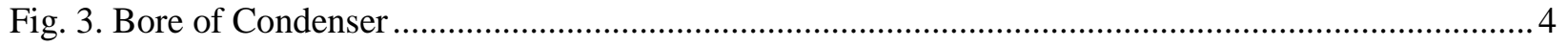

Fig. 4. Physical evidence of pitting corrosion of the stainless steel reactor end plate. …............................ 5

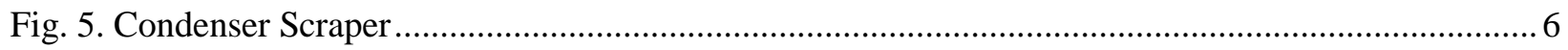

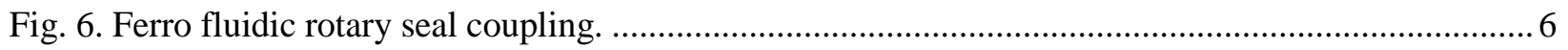

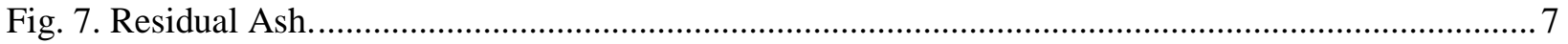

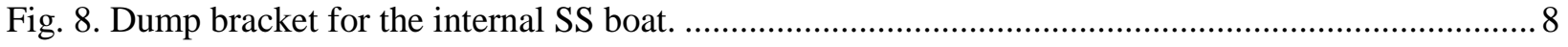

Fig. 9. Turntable Zr reactor support stand for remote handling and rotation............................................. 8

\section{LIST OF TABLES}

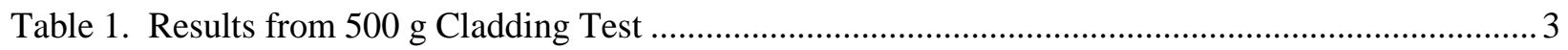

Table 2. Comparison of Iron Concentrations in Product Salt ..................................................................... 4 


\section{Complete Non-Radioactive Operability Tests for Cladding Hull Chlorination}

\section{SUMMARY}

Non-radioactive operability tests were made to test the metal chlorination reactor and condenser and their accessories using batch chlorinations of non-radioactive cladding samples and to identify optimum operating practices and components that need further modifications prior to installation of the equipment into the hot cell for tests on actual used nuclear fuel (UNF) cladding. The operability tests included (1) modifications to provide the desired heating and reactor temperature profile; and (2) three batch chlorination tests using, respectively, 100, 250, and $500 \mathrm{~g}$ of cladding. During the batch chlorinations, metal corrosion of the equipment was assessed, pressurization of the gas inlet was examined and the best method for maintaining solid salt product transfer through the condenser was determined. Also, additional accessing equipment for collection of residual ash and positioning of the unit within the hot cell were identified, designed, and are being fabricated.

\section{INTRODUCTION}

Metal equipment is being prepared for use in future hot cell tests to develop the chlorination process for recovery, purification, and possible recycle of zirconium from used nuclear fuel (UNF) cladding. The primary components of the equipment are (1) a horizontally-oriented chlorination and sublimation reactor, designed to chlorinate 100- to $500 \mathrm{~g}$ batches of UNF cladding, (2), a vertically-oriented condenser to de-sublimate, or condense, the zirconium tetrachloride $\left(\mathrm{ZrCl}_{4}\right)$ salt product, (3) a replaceable bottle for collecting the salt product, and (4) an off-gas line and trapping system for collection of tritium gas released from the cladding during the chlorination and a neutralization trap for excess chlorine $\left(\mathrm{Cl}_{2}\right)$. The reactor is constructed from stainless steel with a nickel-plated internal surface to provide maximum resistance to corrosion, and is equipped with a perforated stainless steel gas inlet and distribution tube and a stainless steel thermocouple well to enable measurement of temperatures inside the reactor. The condenser vessel is also constructed from stainless steel, is equipped with a removable Teflon top plug and rotatable wall scraper (no longer used), plus a conical bottom and O-ring-sealed connection for the replaceable salt product collection bottles, and an off-gas tube. The reactor and condenser vessels are connected with a 4-in.-long, 2-in, diameter stainless steel “neck" tube containing a large Swagelok ${ }^{\circledR}$ connector for separating the two vessels when/if necessary. Top and bottom heating mantles are provided for heating the reactor and neck tube to the reaction temperature $\left(350-400^{\circ} \mathrm{C}\right)$ and the condenser is jacketed for air cooling to $<200^{\circ} \mathrm{C}$ $\left(<50^{\circ} \mathrm{C}\right)$. The test unit and internal reactor removable boat, cladding support screen, and gaseous $\mathrm{ZrCl}_{4}$ filter unit are shown in Fig. 1. 

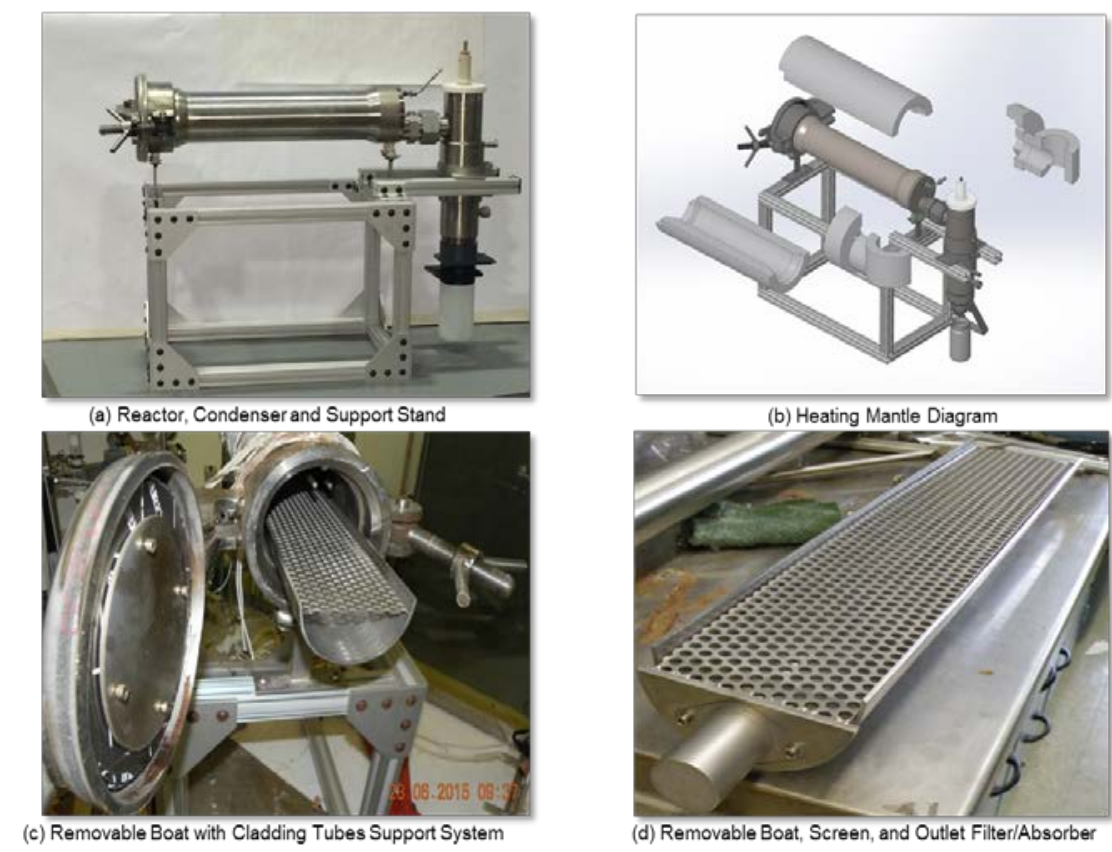

Fig. 1. New metal test equipment for hot cell tests with 100-500g UNF cladding per test.

Initial tests of the assembled equipment in FY 2015 revealed the need for modifications to the reactor charging door, neck piece connector, condenser wall scraper shaft seal, and salt product collector bottle attachment. These modifications were completed by the fabrication shop in October 2015. Prior to leaving the fabrication shop, leak tests to 40 psi were made and no leaks were found. The purpose of the non-radioactive operability tests in FY 2016 was to test the unit with batch chlorination of non-radioactive cladding samples and to identify components that needed further modification to enable satisfactory remote operation after installation in the hot cell.

\section{HEATING TO REACTION TEMPERATURE}

Initial heat testing of the reactor mantles in late FY 2015 had indicated lower than desired temperatures at the clad charging end. With the new, less bulky charging door (Conflat flange and nickel O-ring seal), a heat tape could be wrapped around that end of the reactor to provide extra heat input to provide the desired temperature profile in the reactor. However, the insulated door-cover, which was designed for the original charging door, was not effective for preventing heat losses without added strip insulation pieces. A new insulated cover has been ordered for

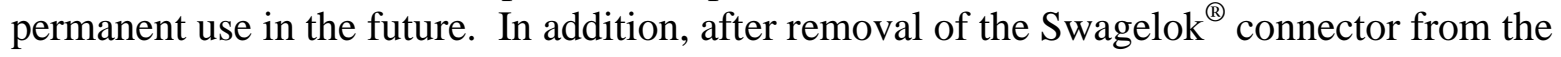
neck piece, another heat tape was wrapped around the neck piece to provide more efficient control of the neck temperature. The addition of the two heat tapes will provide the desired temperature profile control.

\section{CHLORINATION TEST RESULTS AND OBSERVATIONS}


Three batch chlorination tests were made, using sequentially 100, 250, and $500 \mathrm{~g}$ of cladding, to test the operability of the metal equipment and identify needed modifications. In each batch test, the cladding consisted of $90 \%$ Zircaloy- 2 and $10 \%$ Zirlo (high $\mathrm{Nb}$ ) cladding. The test procedure used in each batch test was as follows: (1) Weigh the cladding pieces and place on the removable reactor boat perforated tray, (2) insert the boat and cladding into the reactor, (3) close the flange door and seal with nine nuts, (4) begin Ar flow at $\sim 300 \mathrm{ml} / \mathrm{min}$ and then begin heating reactor with mantles and heat tapes to the reaction temperature of $350^{\circ} \mathrm{C}$, (5) use the heat up period of 3-4 (2-3) hours duration under Ar flow to dry the cladding and internal reactor components, (6) shut off heat input from mantles and start $\mathrm{Cl}_{2}$ flow at 100 (150) $\mathrm{mL} / \mathrm{min}$, then increase $\mathrm{Cl}_{2}$ flow rate as much as possible without exceeding maximum reactor temperature of $395^{\circ} \mathrm{C}$, and finally re-apply heat input as the zirconium is consumed to maintain temperatures $>350^{\circ} \mathrm{C}$, (this step is not normally required) (7) collect $\mathrm{ZrCl}_{4}$ product salt in product bottle(s) at bottom of condenser, (8) when desired amount of product salt has been collected, stop $\mathrm{Cl}_{2}$ flow, turn off heat, and cool down under Ar flow., (9) Obtain weight of product salt and sample for I inductively coupled plasma mass spectrometry (ICPMS) analysis, (10) open reactor door, remove reactor boat, and obtain weight of oxide ash and unreacted cladding pieces, and finally, (11) examine the reactor and condenser internals for residual deposits and equipment corrosion. Temperature control experience in each test showed the reaction rate and heat input from the exothermic reaction could be controlled by regulating the flow rate of the $\mathrm{Cl}_{2}$ reactant. Average reaction rates were 30-40\%/hour during the 100 g test, 15\%/hour during the $250 \mathrm{~g}$ test, and 9\%/hour during the $500 \mathrm{~g}$ test. Faster rates could likely be achieved if the reactor was equipped with a means of heat removal, such as a jacketed vessel with salt solution coolant. During the third test which was made with 500 g cladding, a procedure for stopping $\mathrm{Cl}_{2} \mathrm{flow}_{\text {, }}$ changing the product collector bottle, and then re-starting $\mathrm{Cl}_{2}$ flow was tested and three product salt fractions were collected, containing respectively, 346, 403, and $424 \mathrm{~g}$ of salt for a total of $1.173 \mathrm{~kg}$. Samples of each were analyzed by ICPMS. Results are shown in Table 1:

Table 1. Results from 500 g Cladding Test

\begin{tabular}{|r|c|c|c|c|c|}
\hline Component & Feed Cladding & \multicolumn{4}{|c|}{ Product Salt } \\
\hline Calc. & $\begin{array}{c}1^{\text {st }}(29 \%) \\
\mathrm{ppm} \mathrm{Zr}\end{array}$ & $\begin{array}{c}2^{\text {nd }}(34 \%) \\
\mathrm{ppm} \mathrm{Zr}\end{array}$ & $\begin{array}{c}3^{\text {rd }}(35 \%) \\
\mathrm{ppm} \mathrm{Zr}\end{array}$ & $\begin{array}{c}\text { Condenser Inlet } \\
\text { Deposit } \\
\text { ppm Zr }\end{array}$ \\
\hline $\mathrm{Fe}$ & 1650 & 2,663 & 4,607 & 7,852 & 1,600 \\
\hline $\mathrm{Cr}$ & 920 & $<8$ & 13 & 28 & 89 \\
\hline $\mathrm{Ni}$ & 620 & $<8$ & $<7$ & $<8$ & 16 \\
\hline $\mathrm{Nb}$ & 1,000 & 789 & 1,277 & 1,977 & 150 \\
\hline $\mathrm{Sn}$ & 13,800 & 357 & 1,019 & 197 & 554 \\
\hline
\end{tabular}

\section{Evidence of metal corrosion}

Extra iron, chromium, and nickel are likely due to corrosion of the stainless steel components of the reactor, but the chromium salt is only slightly volatile, appearing only in low concentration in the $2^{\text {nd }}$ and 3rd product samples, while the nickel salt is non-volatile. As indicated in previous tests, iron becomes more volatile, apparently changing from non-volatile $\mathrm{FeCl}_{2}$ to volatile $\mathrm{FeCl}_{3}$, during the course of the batch chlorination. Excess niobium is apparently an analytical variance, but indicates that essentially all niobium is volatile, as previous tests have shown. 
The color of the salt product from the first test was dark orange, indicating the presence of stainless steel corrosion products. Subsequent mass analysis (ICPMS) confirmed the presence of excess iron in the salt product. However, upon disassembly of the test apparatus, very little physical evidence of corrosion was observed, as shown in Figures 2 and 3.

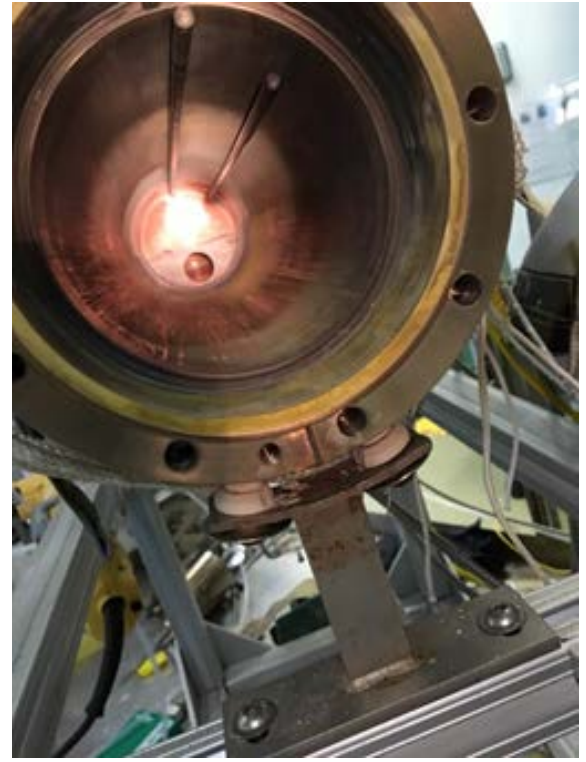

Fig. 2. Bore of Reactor

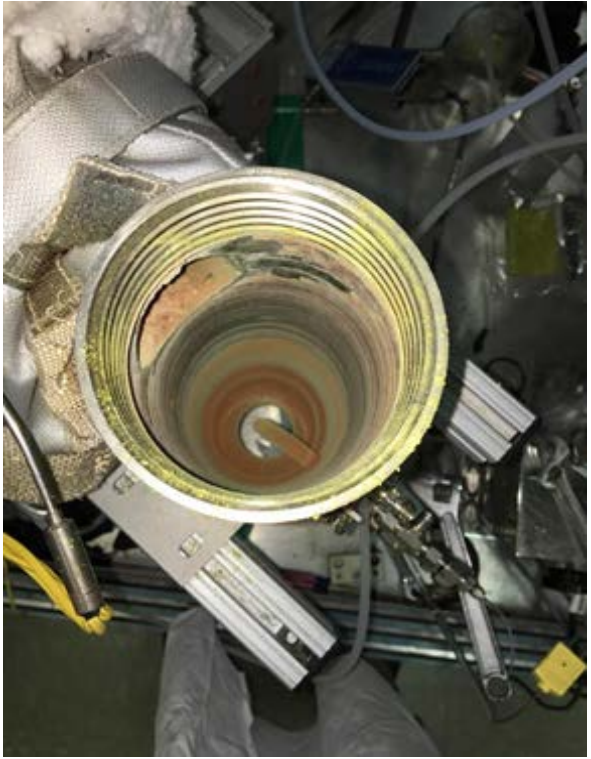

Fig. 3. Bore of Condenser

Table 2 compares the three operability tests made over a 4-month period and indicates that the equipment corrosion and other iron sources are decreasing with exposure of the equipment (as equipment exposure to $\mathrm{Cl}_{2}$ is increasing) .

Table 2. Comparison of Iron Concentrations in Product Salt

\begin{tabular}{|l|c|c|}
\hline & Clad Feed, g & $\begin{array}{c}\text { Product salt } \\
\text { Fe Conc, ppm Zr }\end{array}$ \\
\hline Test 1 (December 2015) & 100 & 31,500 \\
\hline Test 2 (February 2016) & 250 & 12,829 \\
\hline Test 3 (March 2016) & 500 & $2,663-7,852$ \\
\hline
\end{tabular}

However, physical evidence of pitting corrosion of the stainless steel reactor end plate was observed (Fig. 4) after the last chlorination test was completed. The initial design contained a graphite end block which might have protected the end plate from high temperature and exposure to $\mathrm{Cl}_{2}$ but had been removed for spacing purposes prior to testing. This problem must be resolved prior to hot cell installation of the equipment. 


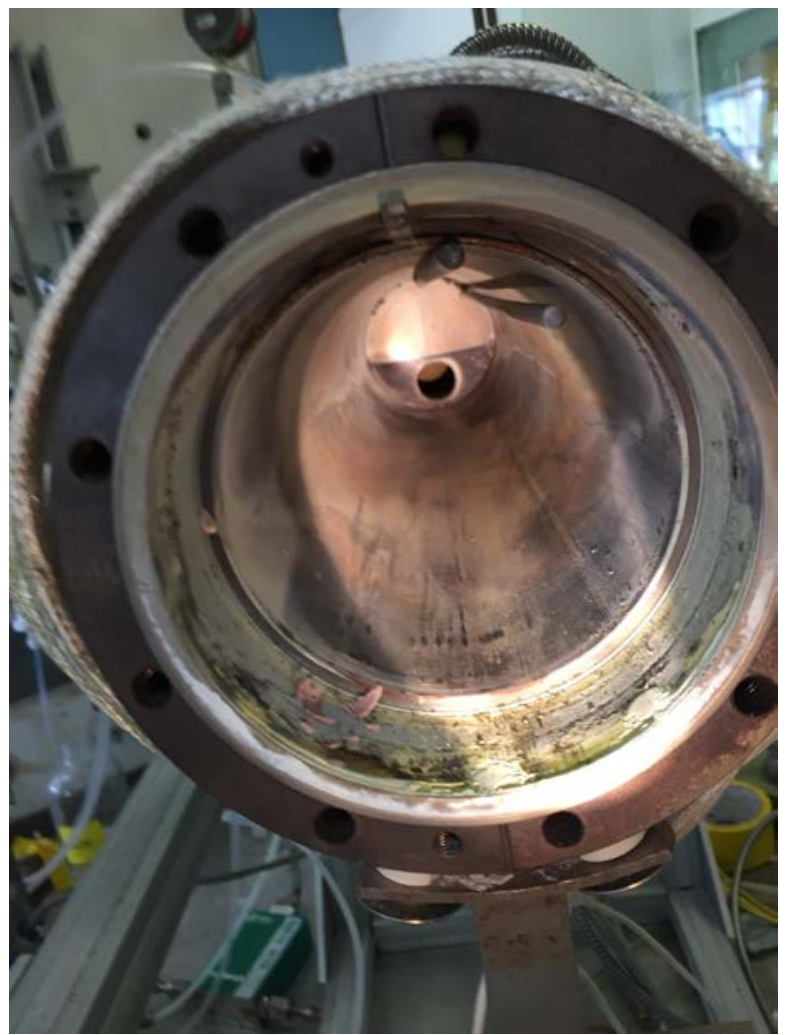

Fig. 4. Physical evidence of pitting corrosion of the stainless steel reactor end plate.

\section{Pressurization of the gas feed line}

Internal pressure began building up in the gas feed line after the first 100 minutes of the first chlorination test and continued increasing until the $\mathrm{Cl}_{2}$ flow rate was stopped; strangely, the pressurization disappeared when only Ar flow remained. Subsequent examination indicated the gas inlet holes in the distributor may be too small, and therefore, the diameter of the holes were widened by reaming with a hand tool prior to the second test. However, pressurization occurred again during the early part of the second chlorination test when $\mathrm{Cl}_{2}$ was introduced at a low rate. Observation revealed a deposit of solids, probably $\mathrm{ZrCl}_{4}$ salt on the gas inlet line. This effect was mitigated by shaking to loosen the deposits, or by increasing $\mathrm{Cl}_{2}$ flow to blow off the deposits. No increase in reactor pressure was observed in the third test.

\section{$\underline{\mathrm{ZrCl}_{4}} \underline{\text { product salt collection }}$}

A vibrator attached to the outside of the condenser, plus periodic manual tapping, were used to maintain flow of the condensed $\mathrm{ZrCl}_{4}$ product salt into the collector bottle. Post-test inspection showed that the inside condenser walls were clean, but a significant salt deposit was accumulated at the condenser gas inlet. Such deposits will require periodic removal. During the first test, a substantial amount of $\mathrm{ZrCl}_{4}$ salt product was deposited on the condenser wall scraper blades (Fig. 5), and during the second test, binding of the rotating wall scraper in the condenser occurred; subsequent disassembly and observation of the ferroseal shaft seal indicated corrosion of the iron component (Fig. 6). 


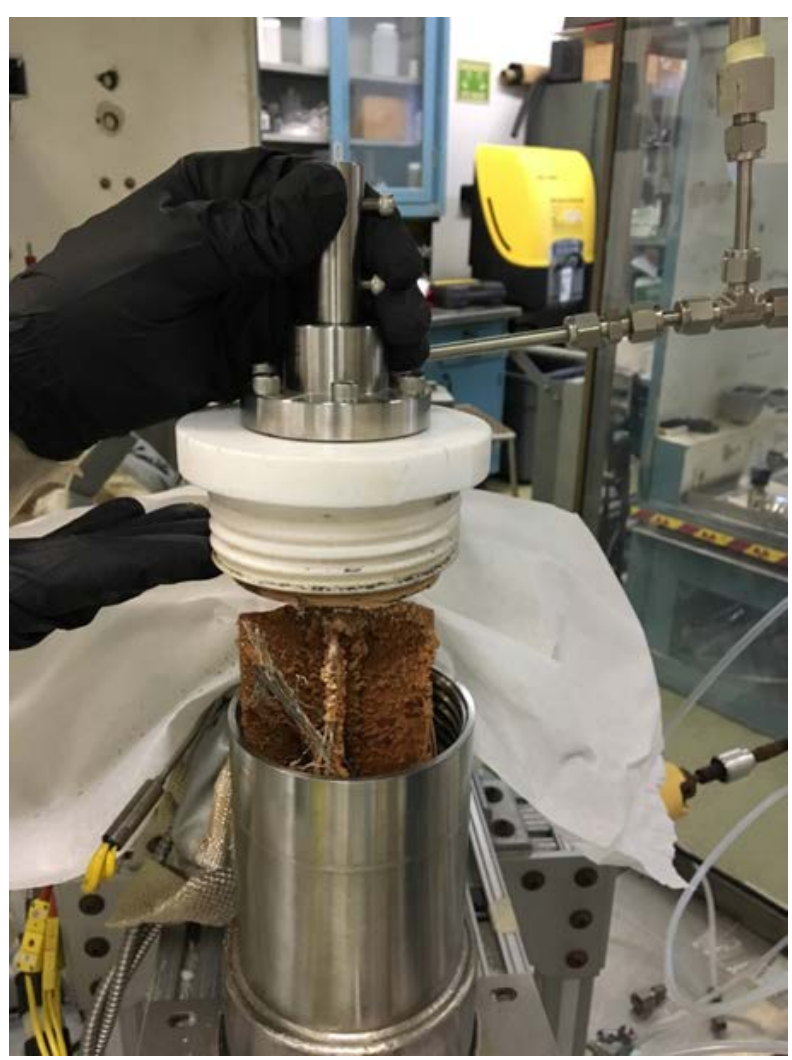

Fig. 5. Condenser Scraper

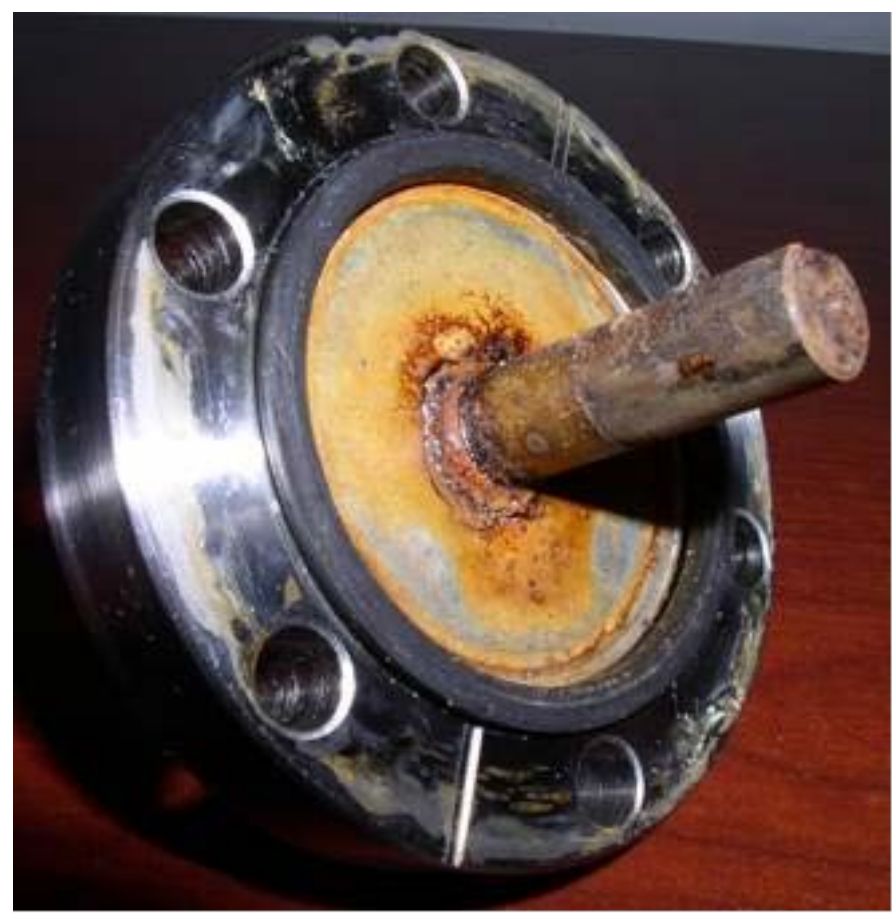

Fig. 6. Ferro fluidic rotary seal coupling. 
Therefore, a decision was made to remove the wall scraper from the condenser and replace the function with an external accelerator applied to the condenser wall to provide continuous or periodic vibration and downward movement of the $\mathrm{ZrCl}_{4}$ product salt into the collector bottle. This method was tested during the third chlorination test and satisfactory performance was achieved; therefore, this method will be used in future hot cell tests.

\section{$\underline{\text { Removal of reactor boat containing oxide ash and unreacted cladding }}$}

Experience with this operation during the tests indicated that the oxide ash remaining on the reactor boat perforated tray was light and fluffy and might be airborne during removal from the reactor (Fig. 7). Therefore, a clamp-on containment tube has been designed as shown in Fig. 8 and will be tested prior to hot cell installation of the equipment.

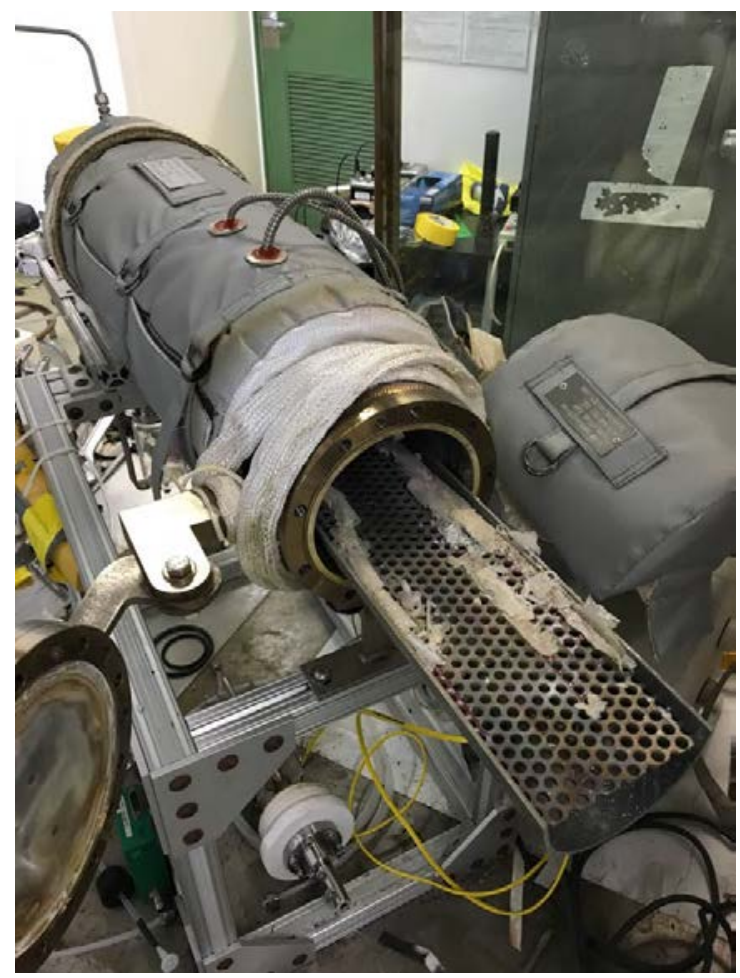

Fig. 7. Residual Ash. 


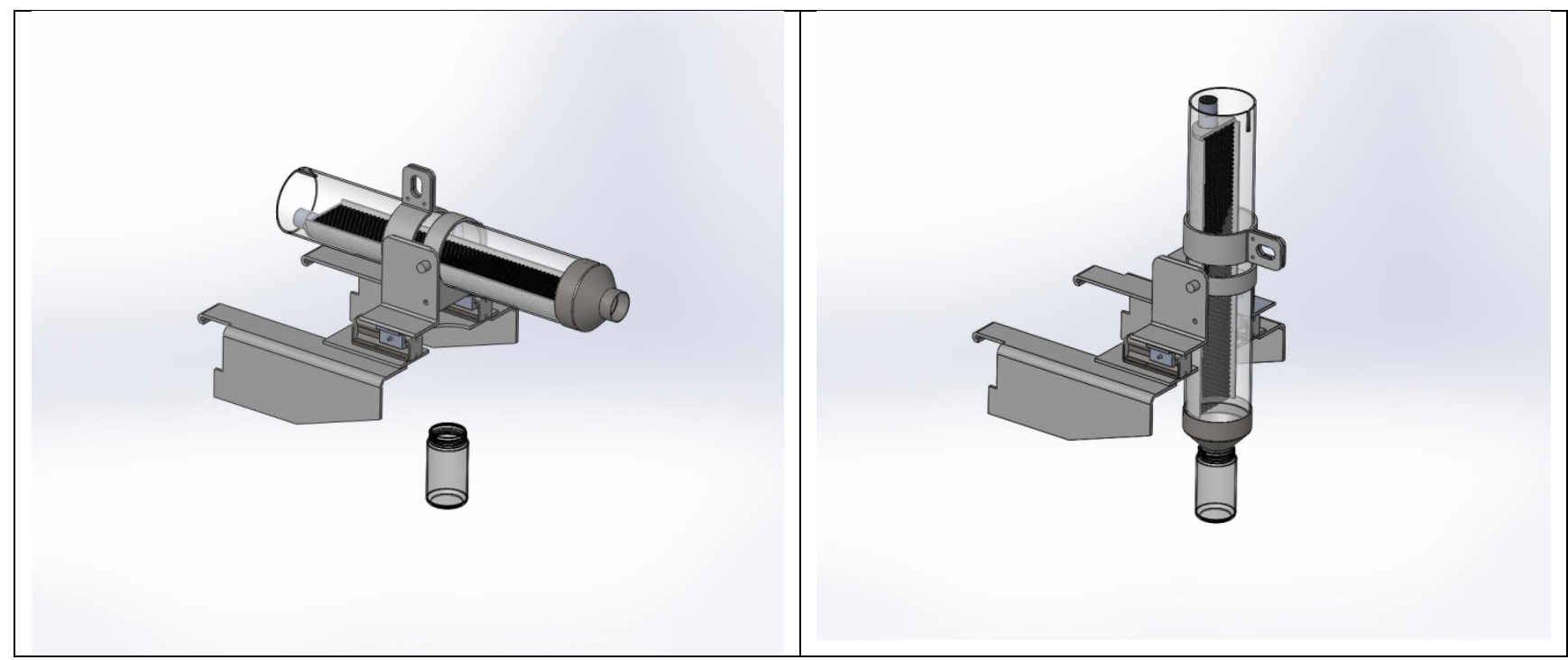

(a) Horizontal position.

(b) Vertical position.

Fig. 8. Dump bracket for the internal SS boat.

\section{Hot cell space and equipment arrangement}

Hot cell management and operators observed the operation of the metal equipment during the second chlorination test, and offered several suggestions for improved operability. In addition, they confirmed that with the small operating table space inside the hot cell (approximately $6 \mathrm{ft} . \mathrm{x}$ $6 \mathrm{ft}$.), the turntable and pedestal base (Fig. 10) will be essential for the manipulator operations that will be necessary (loading cladding and removing ash from the reactor at one end of the support stand, and installing product salt collector bottles at the bottom of the condenser, plus handling off-gas traps for tritium capture at the opposite end of the support rack).

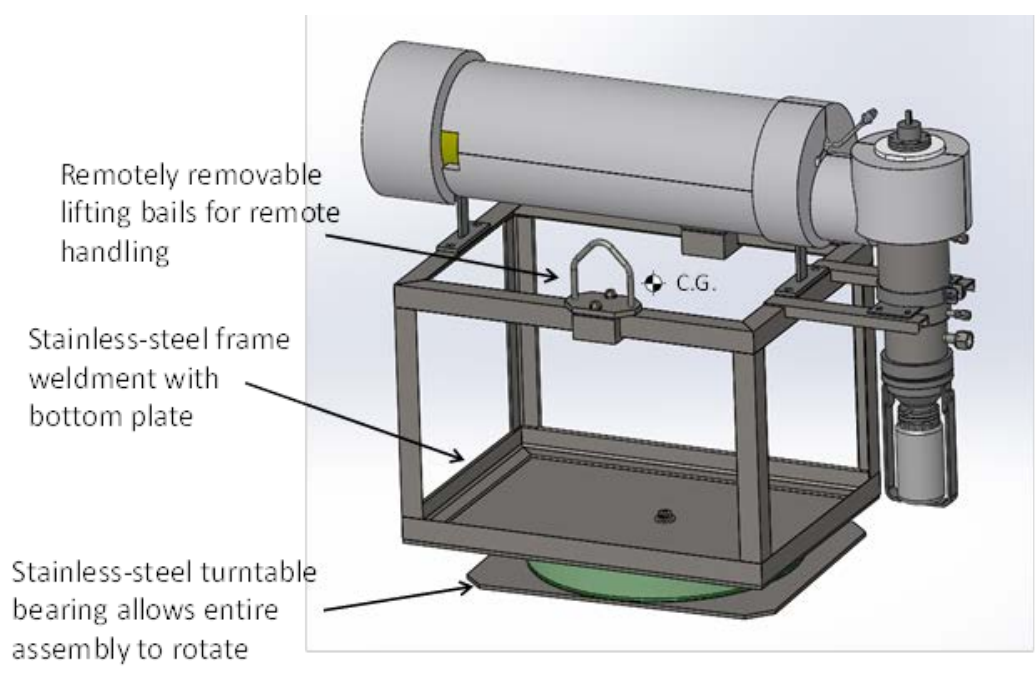

Fig. 9. Turntable Zr reactor support stand for remote handling and rotation. 


\section{CONCLUSIONS}

Two additional heating tapes, in combination with the existing heating mantles were found to provide the desired reactor temperature profile. Elimination of the rotating wall scraper within the condenser and replacement with an external vibrator was found to be the best practice for ensuring collection of the $\mathrm{ZrCl}_{4}$ salt product within the product collector bottles and minimize maintenance operations. Methods for mitigating pressurization of the gas inlet line were developed. Also, accessory equipment was identified and designed to removal of residual ash from the reactor boat and for enabling hot cell manipulator access to both the cladding feed inlet and the opposite -end product collection bottles. Evidence of corrosion of the metal equipment was observed and its severity is being assessed. Focus of the project is now shifted to completion of shop fabrication, and installation of the new accessory equipment and the out-of-cell equipment. 